\title{
Jehan de La Fosse, Les «Mémoires» d'un curé de Paris
} (1557-1590)

\section{Michele Mastroianni}

\section{Q OpenEdition \\ 1 Journals}

\section{Edizione digitale}

URL: http://journals.openedition.org/studifrancesi/30103

DOI: 10.4000/studifrancesi.30103

ISSN: 2421-5856

\section{Editore}

Rosenberg \& Sellier

\section{Edizione cartacea}

Data di pubblicazione: 1 avril 2006

Paginazione: 142

ISSN: 0039-2944

\section{Notizia bibliografica digitale}

Michele Mastroianni, «Jehan de La Fosse, Les «Mémoires» d'un curé de Paris (1557-1590)», Studi

Francesi [Online], 148 (XLX | I) | 2006, online dal 30 novembre 2015, consultato il 19 avril 2021. URL: http://journals.openedition.org/studifrancesi/30103; DOI: https://doi.org/10.4000/studifrancesi. 30103

Questo documento è stato generato automaticamente il 19 avril 2021.

\section{(c) (1)}

Studi Francesi è distribuita con Licenza Creative Commons Attribuzione - Non commerciale - Non opere derivate 4.0 Internazionale. 


\title{
Jehan de La Fosse, Les «Mémoires» d'un curé de Paris (1557-1590)
}

\author{
Michele Mastroianni
}

\section{NOTIZIA}

JEHAN DE LA FOSSE, Les «Mémoires» d'un curé de Paris (1557-1590), édités par MARC VENARD, Genève, Droz («Travaux d'Humanisme et Renaissance, CCCXCIII»), 2004, pp. 199.

1 Nel 1866, col titolo Journal d'un curé ligueur de Paris sous les trois derniers Valois, Édouard de Barthélemy aveva apprestato un'edizione del testo di Jehan de La Fosse, assolutamente scorretta e inaffidabile per i numerosissimi errori di trascrizione, per i tagli ingiustificati e non segnalati, per le affermazioni erronee che si scoprono nel commento. Ora, Marc Venard, insigne storico della Chiesa cinquecentesca, offre l'edizione auspicata, paleograficamente corretta, del manoscritto parigino BN fr. 5549 (manoscritto peraltro di non facile lettura), e la accompagna con una limpida introduzione (pp. 7-28) e con un'annotazione puntuale. Viene offerta così agli storici delle guerre di religione in Francia una testimonianza interessante sugli anni 1557-1590. Interessante, non perché il nostro curato parigino sia un grande personaggio, con accesso ai centri nodali della politica, o una mente di grande levatura intellettuale; ma proprio perché il suo diario è un documento delle reazioni del 'popolo' al grande scontro politico e religioso in corso. In quanto «testimone della strada, dei suoi rumori e delle sue passioni, Jehan de La Fosse è un testimone unico in seno al clero parigino» (p. 11). La testimonianza è quella del fedele alla casata dei Guise più che quella di un partigiano incondizionato della Ligue: anzi intorno al 1590, quando Enrico IV non avrà più veri ostacoli al suo riconoscimento, Jehan de La Fosse esprimerà il senso comune del borghese parigino prendendo le distanze dalle posizioni dei ligueurs fanatici. Non ci si può dunque che rallegrare di questa edizione esemplare. Un unico rimpianto - che concerne più che lo storico il linguista - riguarda il glossario che 
sarebbe stato forse auspicabile rendere meno esiguo, dato lo straordinario interesse, a parere nostro, del testo anche come testimonianza linguistica. 